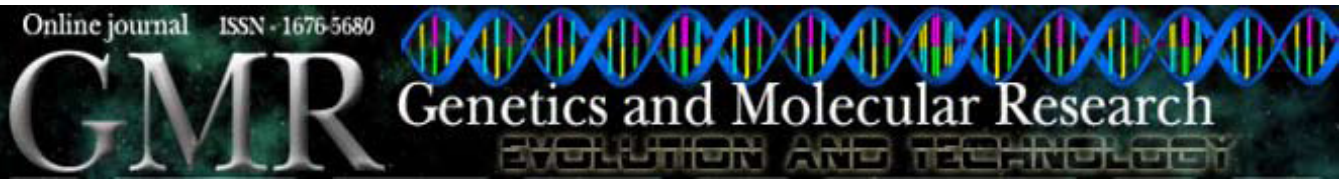

\title{
Endophytic and pathogenic isolates of the cacao fungal pathogen Moniliophthora perniciosa (Tricholomataceae) are indistinguishable based on genetic and physiological analysis
}

T.G. Lana ${ }^{1}$, J.L. Azevedo ${ }^{1}$, A.W.V. Pomella ${ }^{2}$, R.T.R. Monteiro ${ }^{3}$, C.B. Silva ${ }^{4}$ and W.L. Araújo ${ }^{4}$

'Departamento de Genética, Escola Superior de Agricultura "Luiz de Queiroz", Universidade de São Paulo, Piracicaba, SP, Brasil

${ }^{2}$ Almirante Cacau, Itajuípe, BA, Brasil

${ }^{3}$ Centro de Energia Nuclear na Agricultura,

Universidade de São Paulo, Piracicaba, SP, Brasil

${ }^{4}$ Laboratório de Biologia Molecular e Ecologia Microbiana, NIB,

Universidade de Mogi das Cruzes, Mogi das Cruzes, SP, Brasil

Corresponding author: W.L. Araújo

E-mail: welingtonluiz@umc.br

Genet. Mol. Res. 10 (1): 326-334 (2011)

Received June 28, 2010

Accepted January 5, 2011

Published February 22, 2011

DOI 10.4238/vol10-1gmr895

ABSTRACT. We evaluated the genetic and physiological variability of Moniliophthora perniciosa obtained from healthy and diseased branches of cacao (Theobroma cacao) plants. The diversity of the isolates was evaluated by RAPD technique and by studies of virulence and exoenzyme production. The genetic variability of endophytic and pathogenic M. perniciosa was evaluated in association with pathogenicity assays. RAPD analysis showed eight genetic groups, which were not related to plant disease status (healthy versus diseased branches). Isolates from cacao were included in three groups, excluding isolates from other host plants. Pathogenicity and enzyme analysis showed that the virulence of the isolates is not 
related to exoenzyme production. This is the first evidence that $M$. perniciosa colonizes healthy parenchymatic tissues, showing that endophytic behavior may occur in this species.

Key words: Cacao; Genetic variability; RAPD; Witches' broom; Exoenzymes

\section{INTRODUCTION}

The basidiomycete Moniliophthora perniciosa (formerly Crinipellis perniciosa (Stahel) Singer) is the causal agent of witches' broom disease of cacao (Theobroma cacao L.). Witches' broom is one of the main limiting factors for cacao production in South America and Caribbean islands, and is considered to be one of the most important pathogens for the crop (Griffith et al., 1994). The infection process occurs after basidiospore germination and penetration of the germ tube into meristematic tissues and pods (Orchard et al., 1994), starting the biotrophic stage of colonization (Muse et al., 1996). This phase is characterized by intercellular growth, thick and monokariotic hyphae without clamp connections (Calle et al., 1982; Silva and Matsuoka, 1999). In the next phase, the saprophytic stage, necrosis and intracellular colonization by dikaryotic hyphae occur (Muse et al., 1996).

The determination of the genetic variability of the pathogen is an important aspect for the selection of resistant genotypes in breeding programs. The characterization of different $M$. perniciosa isolates has been done by testing the pathogenicity with artificial inoculation (Bastos et al., 1988; Wheeler and Mepsted, 1988), somatic incompatibility assays and by assessing the biochemistry profile during the saprophytic phase (Griffith and Hedger, 1994). Molecular markers, including random amplified polymorphic DNA (RAPD), have also been used in studies of genetic diversity of plant-associated fungi (Anderbrhan and Furtek, 1994; Yamada et al., 1998; Anderbrhan et al., 1999; Sebastianes et al., 2007).

Endophytic fungi colonize their hosts without causing any external disease symptoms (Carroll, 1988), except when the host is under stress conditions. Studies on microorganisms from tropical plant species have recently become more frequent, since these fungi and bacteria are now studied for biological control and production of compounds with pharmacological properties (Araújo et al., 2008). Studies on the cacao endophytic community are recent, but practical aspects have been already evaluated (Arnold et al., 2003; Rubini et al., 2005). On the other hand, more studies on witches' broom disease and endophytic community interaction should be carried out.

Hypovirulent fungal strains can also be used on the biocontrol of plant diseases, as reported by Manandhar et al. (1998), when a hypovirulent Pyricularia oryzae isolate was able to reduce significantly neck blast caused by virulent strain under field conditions. Because of the pathological importance of M. perniciosa, the genetic (based on RAPD markers) and physiological (based on pathogenicity and extracellular enzymatic activity) analyses were used to distinguish isolates obtained from healthy and diseased cacao tissues. Therefore, the aim of the present study was to isolate M. perniciosa from healthy cacao tissues, and evaluate the pathogenicity of this isolate. This approach was used to 
evaluate the presence of avirulent genotypes in healthy plants, which could be used in cross-inoculation for disease control, or to determine if the resistant plants could be used as a reservoir for pathogenic strains.

\section{MATERIAL AND METHODS}

\section{Isolation of M. perniciosa from cacao}

The M. perniciosa strains evaluated for this study were obtained from freshly cut healthy and infected cacao branches collected from different 20- to 40-year-old trees, located in Uruçuca and Lomanto Júnior, Bahia, Brazil. Fragments $(12 \mathrm{~cm})$ of cacao branches were surface disinfected according to Araújo et al. (2001). After disinfection, the bark was removed and branches were cut, and pieces $(1 \mathrm{~cm})$ were placed onto PDA (potato dextrose agar, Merck) medium containing tetracycline $(50 \mu \mathrm{g} / \mathrm{mL})$ and incubated for 5-20 days at $28^{\circ} \mathrm{C}$. Colonies, from plant fragments, morphologically similar to M. perniciosa, were selected for further analysis. These isolates were identified based on hyphal morphology and rDNA sequencing. Isolates from other Brazilian cacao regions and also from different hosts were kindly supplied by cacao researchers and included in the present study for comparison (Table 1). For isolation of M. perniciosa from healthy tissues, fresh branches were collected from completely asymptomatic plants.

\section{Pathogenicity assay}

Pathogenicity of the M. perniciosa isolates $(5,6,8,9,10,31,79$, and FA284) was evaluated. The isolate FA42 was used as the positive control due to the high virulence exhibited in previous trials. Mycelial plugs from M. perniciosa cultures on PDA plates were transferred to Petri dishes filled with a sterile substrate for M. perniciosa basidiocarp development ( $517 \mathrm{~g}$ ground dry brooms, $21 \mathrm{~g} \mathrm{Ca}_{2} \mathrm{SO}_{4}, 138 \mathrm{~g}$ oat flour in $700 \mathrm{~mL}$ water). After substrate colonization, the plates were transferred to humid chambers at $28^{\circ} \mathrm{C}$. Formation of basidiocarps commenced after 30 days. Spore suspensions were prepared according to Frias et al. (1995), where fresh basidiocarps were stuck on the inside of the lid of a Petri dish and basidiospores were collected in a $16 \%(\mathrm{v} / \mathrm{v})$ glycerol solution.

Forty-five-day-old seedlings of the susceptible variety "common cacao" were inoculated by deposition of $50 \mu \mathrm{L}$ of a $5 \times 10^{5}$ basidiospores $/ \mathrm{mL}$ suspension on the apical active meristematic tissue. After inoculation, the seedlings were maintained in humid chambers for $48 \mathrm{~h}$ and then placed in the greenhouse. Evaluation was done after 60 days of the recording by checking the disease incidence. The experiment was designed in randomized blocks with three replicates, where each replicate consisted of five seedlings. Plants inoculated with sterile distilled water were used as controls. The presence or absence of diseased seedling in each replicate was counted and the frequency was calculated.

\section{Extracellular enzyme production}

All strains reported in Table 1 were evaluated for enzymatic activity on solid medium. Mycelial plugs $(8 \mathrm{~mm}$ ), from young colony (approximately 5 days old) borders, were 
individually transferred to minimal medium - MM (Pontecorvo et al., 1953), without glucose, supplemented with different carbon sources according to the exoenzyme activity evaluation. All plates were incubated for 11 days at $28^{\circ} \mathrm{C}$, when the halo/colony ratio was measured. The strains were evaluated using 3 replicates started at different times.

Lipase activity was evaluated on MM supplemented with Tween ${ }^{\circledR} 20(1 \%$ - v/v). After fungal growth the culture was incubated at $4^{\circ} \mathrm{C}$ for $24 \mathrm{~h}$ and lipase production was measured by halo formation around the fungal colony. Amylase production was evaluated on MM supplemented with $1 \%(\mathrm{w} / \mathrm{v})$ soluble starch. After fungal growth, $10 \mathrm{~mL}$ iodine solution $(10$ g iodine, $6 \mathrm{~g}$ potassium iodide dissolved in $20 \mathrm{~mL}$ water and the volume completed to 100 $\mathrm{mL}$ with ethanol) was added on the colony and the enzyme production was characterized by halo formation. Pectinase activity was determined on modified $\mathrm{MM}\left(7 \mathrm{~g} / \mathrm{L} \mathrm{K}_{2} \mathrm{HPO}_{4}, 2\right.$ $\mathrm{g} / \mathrm{L} \mathrm{KH}_{2} \mathrm{PO}_{4}, 1 \mathrm{~g} / \mathrm{L}\left(\mathrm{NH}_{4}\right)_{2} \mathrm{SO}_{4}, 0.5 \mathrm{~g} / \mathrm{L} \mathrm{MgSO}{ }_{4} .7 \mathrm{H}_{2} \mathrm{O}, 10 \mathrm{~g} / \mathrm{L}$ citric pectin, $\left.\mathrm{pH} 6.8\right)$. The halo was measured after adding a $1 \%(\mathrm{w} / \mathrm{v})$ solution of hexadecyltrimethylammonium bromide. The endoglucanase activity was evaluated after fungal growth on MM supplemented with carboxymethylcellulose. Congo red solution $(0.1 \%-\mathrm{w} / \mathrm{v})$ was added to the colony and then rinsed with $4 \mathrm{M} \mathrm{NaCl}$. Finally, the growth of M. perniciosa strains on MM supplemented with $1 \%(\mathrm{w} / \mathrm{v})$ Sigmacel indicated the production of endo- and exoglucanases.

\section{RAPD analysis}

Total DNA was extracted according to Raeder and Broda (1985). RAPD analysis was carried out in $25-\mu \mathrm{L}$ reactions, containing $10 \mathrm{ng}$ template DNA, $2.5 \mathrm{mM}$ each of dNTP (Invitrogen), $5 \mathrm{mM} \mathrm{MgCl}{ }_{2}, 2.5 \mathrm{U}$ Taq DNA polymerase (Invitrogen), and $0.4 \mu \mathrm{M}$ primer (OPA07, OPA16, OPA20, OPAX10, OPAX03, OPAX20, OPC08, OPP16, or OPX17; Operon Technologies, USA) in $10 \mathrm{mM}$ Tris-HCl, $\mathrm{pH} 8.4$, containing $10 \mathrm{mM} \mathrm{KCl}$. The amplification conditions were 5 min at $94^{\circ} \mathrm{C}$, followed by 40 cycles of $1 \mathrm{~min}$ at $92^{\circ} \mathrm{C}, 1 \mathrm{~min}$ at $35^{\circ} \mathrm{C}, 3 \mathrm{~min}$ at $72^{\circ} \mathrm{C}$ with a final extension at $72^{\circ} \mathrm{C}$ for $5 \mathrm{~min}$. Polymerase chain reaction (PCR) products were analyzed on $1.4 \%$ agarose gel. Negative controls contained water instead of DNA.

\section{Data analysis}

The Dunnett test $(\mathrm{P}=0.01)$ was used for statistical analysis and data comparisons were made using the strains FA42 as control. A dendrogram based on simple matching was constructed using unweighted pair group method with averages (UPGMA) cluster analysis. A consensus tree was obtained using the Winboot software (Yap and Nelson, 1996) with the bootstrap replicate number test set at 1000 .

\section{RESULTS}

\section{Isolation and pathogenicity of $C$. perniciosa}

Two strains of $M$. perniciosa (31 and 54) isolated from healthy tissues of highly resistant and asymptomatic plants were considered to be endophytes; 11 strains $(1,2,3$, $4,5,6,7,8,9,10$, and 79) were obtained from diseased tissues of susceptible plants. Although the strains 31 and 54 were obtained from healthy plants, they were able to in- 
duce witches' broom symptoms in inoculated seedlings at the same frequency as strains obtained from diseased branches. After 15 days a typical swelling at the apical meristem of the infected plants was observed. The disease frequency ranged from 53.3 to $100 \%$ for isolates 10 and FA42, respectively. The endophytic isolate 31 induced disease symptoms in $60 \%$ of the inoculated seedlings.

\section{RAPD analysis}

RAPD analysis of $35 \mathrm{M}$. perniciosa isolates (Table 1), using nine primers, generated 57 polymorphic bands that ranged from 600 to $3000 \mathrm{bp}$. These bands were used to construct a dendrogram (Figure 1). Eight major groups were identified (Figure 1 and Table 1); the cacao strain was included in groups G1, G2 and G3, while strains from other plant hosts were included in other groups. Endophytes were included in G2, but were indistinguishable from the pathogenic strains. Strains 1, 2, 3, 4, 5, and 6 were obtained from the same green broom and were arranged in the same group, as expected. They were also grouped together with the pathogenic isolates FA154 and FA152, isolated from cacao in Rondônia, a Brazilian State located $2000 \mathrm{~km}$ from Bahia.

\begin{tabular}{|c|c|c|c|c|c|c|c|c|}
\hline \multirow[t]{2}{*}{ Strains } & \multirow[t]{2}{*}{ Isolation site } & \multirow[t]{2}{*}{ Host plant $^{\S}$} & \multirow{2}{*}{$\begin{array}{l}\text { RAPD } \\
\text { group }\end{array}$} & \multicolumn{5}{|c|}{ Extracellular enzymes } \\
\hline & & & & Amyl & Pect & Egl & Lip & $\mathrm{SiC}$ \\
\hline FA42 & Lomanto Junior/BA & Cacao & G2 & - & - & - & - & - \\
\hline $1,5,6$, FA23 & Uruçuca/BA & Cacao & G1 & $\mathrm{B}$ & $\mathrm{B}$ & $\mathrm{B}$ & $\mathrm{B}$ & $\mathrm{C}$ \\
\hline 2 & Uruçuca/BA & Cacao & G1 & $\mathrm{B}$ & A & B & B & B \\
\hline 3 & Uruçuca/BA & Cacao & G1 & B & $\mathrm{B}$ & $\mathrm{B}$ & B & $\mathrm{B}$ \\
\hline 4 & Uruçuca/BA & Cacao & G1 & B & $\mathrm{B}$ & $\mathrm{B}$ & B & B \\
\hline FA154 & Ariquemes /RO & Cacao & G1 & $\mathrm{A}$ & $\mathrm{B}$ & B & B & B \\
\hline FA27, FA282 & Lomanto Junior/BA & Cacao & G1 & $\mathrm{B}$ & B & $\mathrm{B}$ & B & $\mathrm{C}$ \\
\hline FA278 & Lomanto Junior/BA & Cacao & G1 & $\mathrm{B}$ & $\mathrm{C}$ & $\mathrm{B}$ & $\mathrm{B}$ & $\mathrm{B}$ \\
\hline FA279 & Uruçuca/BA & Cacao & G1 & B & $\mathrm{B}$ & $\mathrm{B}$ & B & $\mathrm{C}$ \\
\hline FA283 & Lomanto Junior/BA & Cacao & G1 & B & B & A & B & $\mathrm{C}$ \\
\hline FA286 & Inema/BA & Cacao & G1 & $\mathrm{A}$ & $\mathrm{B}$ & $\mathrm{A}$ & $\mathrm{B}$ & $\mathrm{C}$ \\
\hline FA287 & Inema/BA & Cacao & G1 & $\mathrm{B}$ & $\mathrm{B}$ & $\mathrm{B}$ & $\mathrm{B}$ & $\mathrm{B}$ \\
\hline FA292 & Itapé/BA & Cacao & G1 & $\mathrm{B}$ & $\mathrm{B}$ & $\mathrm{B}$ & $\mathrm{B}$ & $\mathrm{C}$ \\
\hline FA35 & Belém/PA & Cacao & G1 & B & B & $\mathrm{B}$ & B & $\mathrm{B}$ \\
\hline FA152 & Ouro Preto/RO & Cacao & G1 & $\mathrm{A}$ & $\mathrm{B}$ & $\mathrm{B}$ & B & $\mathrm{C}$ \\
\hline 10 & Lomanto Junior/BA & Cacao & G2 & $\mathrm{B}$ & $\mathrm{C}$ & $\mathrm{B}$ & B & A \\
\hline 31 & Uruçuca/BA & Cacao & $\mathrm{G} 2$ & $\mathrm{~A}$ & $\mathrm{~B}$ & $\mathrm{~B}$ & $\mathrm{~B}$ & $\mathrm{~B}$ \\
\hline 54 & Uruçuca/BA & Cacao & $\mathrm{G} 2$ & A & B & $\mathrm{A}$ & B & $\mathrm{C}$ \\
\hline 7 & Lomanto Junior/BA & Cacao & $\mathrm{G} 2$ & B & B & $\mathrm{B}$ & B & $\mathrm{B}$ \\
\hline 79 & Uruçuca/BA & Cacao & $\mathrm{G} 2$ & $\mathrm{~A}$ & $\mathrm{~B}$ & $\mathrm{~B}$ & B & B \\
\hline 8,9 & Lomanto Junior/BA & Cacao & $\mathrm{G} 2$ & A & $\mathrm{A}$ & $\mathrm{B}$ & $\mathrm{B}$ & $\mathrm{C}$ \\
\hline FA276 & Lomanto Junior/BA & Cacao & $\mathrm{G} 2$ & $\mathrm{~B}$ & A & $\mathrm{B}$ & $\mathrm{B}$ & A \\
\hline FA281 & Aiquara/BA & Cacao & $\mathrm{G} 2$ & B & $\mathrm{C}$ & B & B & A \\
\hline FA284 & Barra do Rocha/BA & Cacao & $\mathrm{G} 2$ & B & $\mathrm{B}$ & B & B & B \\
\hline 11 & Rondônia & Cacao & G3 & $\mathrm{B}$ & B & $\mathrm{B}$ & $\mathrm{B}$ & $\mathrm{C}$ \\
\hline 12 & Unknown & Solanum sp & G6 & $\mathrm{A}$ & $\mathrm{A}$ & $\mathrm{B}$ & $\mathrm{B}$ & $\mathrm{C}$ \\
\hline 13 & Unknown & S. licocarpum & G4 & $\mathrm{B}$ & $\mathrm{B}$ & $\mathrm{B}$ & B & $\mathrm{C}$ \\
\hline FA104 & Viçosa/MG & S. cernuun & G5 & $\mathrm{B}$ & $\mathrm{C}$ & $\mathrm{B}$ & B & $\mathrm{C}$ \\
\hline FA136 & Ecuador & Liana & G7 & B & $\mathrm{C}$ & $\mathrm{B}$ & B & $\mathrm{C}$ \\
\hline 322 & Ecuador & Liana & G8 & $\mathrm{B}$ & $\mathrm{C}$ & A & B & B \\
\hline
\end{tabular}

${ }^{\S}$ All strains were isolated from symptomatic branches, except strains 31 and 54, which were isolated from healthy branches, obtained from resistant asymptomatic plants. Amyl = amylase; Pect = pectinase; Egl = endoglucanases; $\mathrm{Lip}=$ lipases; $\mathrm{SiC}=$ production of endo- and exoglucanases; $\mathrm{A}=$ halo/colony $(\mathrm{H} / \mathrm{C})$ ratio higher than the strain FA42; $B=H / C$ similar to the strains FA42; $C=H / C$ lower than the strains FA42 (Dunnett test, $\mathrm{P}>0.01$ ). 


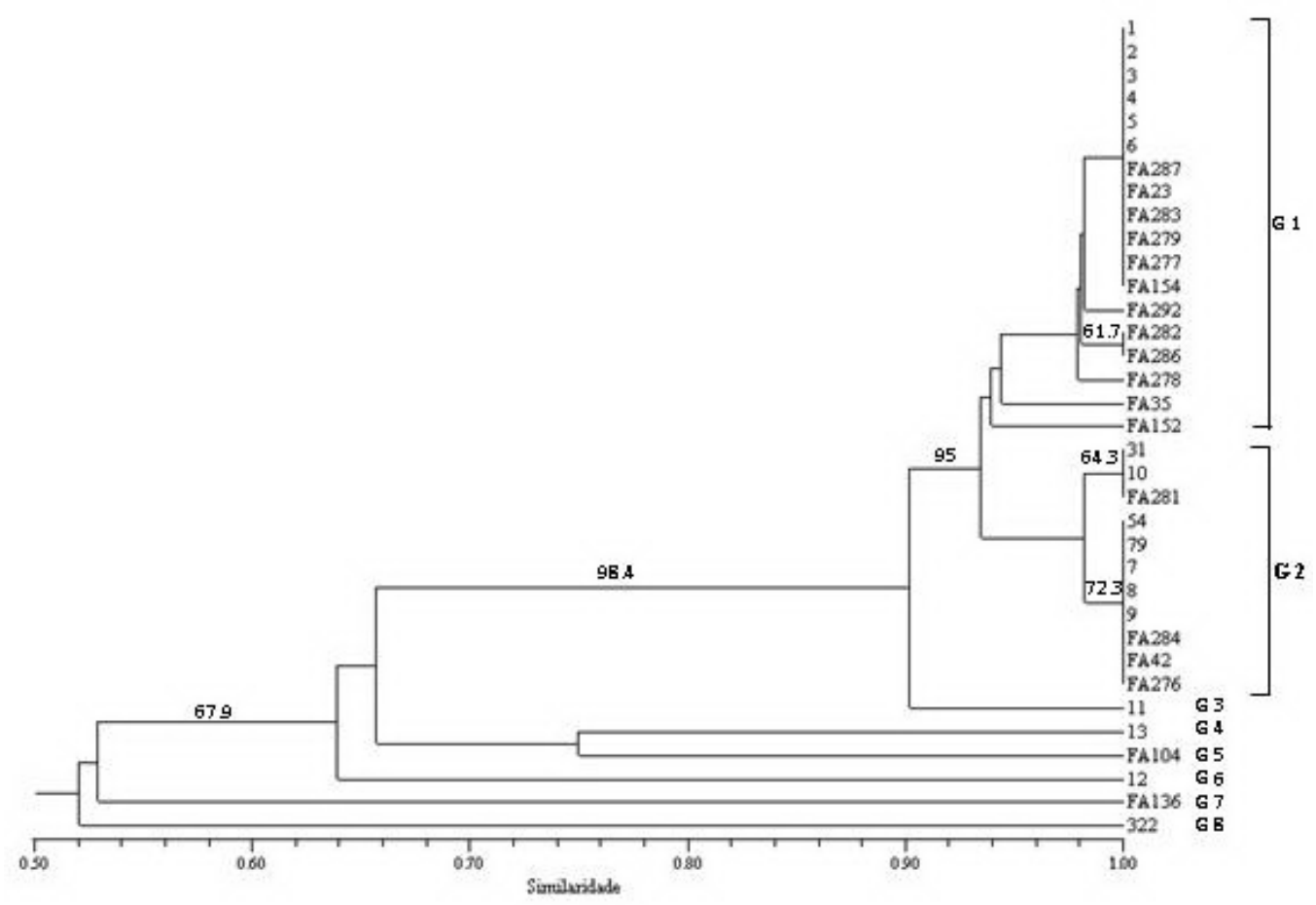

Figure 1. Dendrogram showing genetic relationships among Moniliophthora perniciosa isolates based on RAPD analysis. Bootstrap values (based on 1000 bootstrap samples) are placed on the tree.

\section{Extracellular enzyme production}

Lipase production by the strains evaluated did not differ from that of control strain FA42 (Table 1). Production of extracellular pectinases, amylase, exo- and endoglucanases allowed differentiation of the assayed isolates. However, this differentiation was not related to pathogenic/endophytic behavior (Table 1). The isolates 10, FA104, FA136, FA278, and FA281 did not produce detectable pectinases, while the isolates 54, FA283, FA286, and 322 showed higher production of endoglucanase than the isolate FA42 (Table 1). Isolates obtained from the same infected sample $(1,2,3,4,5$, and 6$)$ showed different enzymatic activity. The endophytic isolate 31 was distinguished from FA42 only based on amylase production, while the endophytic isolate 54 was distinguished by amylase and exo- and endoglucanase.

\section{DISCUSSION}

Endophytic and pathogenic strains of M. perniciosa were characterized by RAPD banding patterns and were compared for their pathogenicity in cacao and their production of exoenzymes. Although the isolates 1, 2, 3, 4, 5, and 6, obtained from the same infected branch, showed the same RAPD profile, the exoenzyme production differentiated these 
isolates, indicating that genetically different strains may colonize the same plant tissue despite having different virulence expressions. Similar results were obtained by Araújo et al. (2001) demonstrating that more than one strain of the same species of bacterium could be endophytic within an individual citrus plant. Anderbrhan and Furtek (1994) found that several basidiospores could share the same infection site in the field and, by RAPD analysis, a genetic heterogeneity was found in one monosporic culture, when compared with seven others, isolated from the same basidiocarp produced on Solanum rugosum. The presence of more than one genotype of M. perniciosa colonizing the same tissue can allow hyphal anastomosis leading to further heterokaryosis and eventually increasing genetic diversity in basidiospore generations (Wheeler and Mepsted, 1988).

M. perniciosa was isolated from healthy plant tissues. This is the first report of asymptomatic colonization of cacao tissues by M. perniciosa apart from apical meristems and buds. Because bark was removed from branches and the buds were removed, it is unlikely that the endophytic strains arose from meristematic tissues, where M. perniciosa may remain in latent infection. This suggests that the endophytic asymptomatic infection of cacao trees by this pathogen may be from common plant-pathogenic Colletotrichum species that are able to asymptomatically colonize plants and express nonpathogenic lifestyles, conferring disease resistance, drought tolerance, and/or plant growth promotion (Redman et al., 2001).

RAPD analysis, pathogenicity tests and enzyme production did not reveal any genetic differences between endophytic and pathogenic isolates. In fact, the ability to induce disease symptoms may be under the control of a few genes, which could not be detected by these analyses. Freeman and Rodriguez (1993) observed that a mutation at a single locus could transform a virulent strain of Colletotrichum magna into an avirulent strain that was able to colonize its host endophytically; moreover, prior infection with the mutant protected plants against the wild type. The isolate 31 was virulent when inoculated onto seedlings, but this result may be explained by the high concentration of the spore in the inoculum suspension, since in the field the disease pressure would not reach that level. Mutualistic effects, such as induction of resistance will be further evaluated for endophytic strains 31 and 54 .

The isolate 31 was virulent when inoculated on seedlings, but this result may be explained by the high concentration of the spore suspension inoculated, since in the field the disease pressure would not reach that level. Mutualistic effects, like resistance induction, have to be further evaluated for isolates 31 and 54. Sinclair and Cerkauskas (1996) clearly distinguished endophytic colonization and latent infection, based on the harmful effect on the host caused by pathogens. Latent infection is the state in which a host is infected with a pathogen but does not show symptoms and persists until signs or symptoms are prompted to appear by environmental or nutritional conditions or by the state of maturity of the host or pathogen (Agrios, 1988). The situation presented here indicates that the isolates of M. perniciosa obtained from a resistant host may be a pathogenic genotype that is able to colonize the resistant plant in latent state. Further investigation needs to be done to clarify if it will complete its life cycle after the plant dies, behaving like M. perniciosa L-type, which produces basidiocarp only on dead Liana-infected tissue (Evans HC, personal communication). In light of this, our future study will be directed at analyzing the nature of these isolates and the mechanisms involved in the endophytic colonization of cacao by M. perniciosa. 


\section{ACKNOWLEDGMENTS}

Research supported by a grant from the Foundation for Research Assistance, São Paulo State, Brazil (FAPESP). We thank CAPES for the fellowship to T.G. Lana. We also thank Dr. Ricardo Harekava (Instituto Biológico, São Paulo, Brazil) for DNA sequencing, Dr. Robert Barreto, Dr. Harry Evans, Dr. Gareth Griffith, and Dr. Luiza Nakayama for providing some of the Moniliophthora perniciosa isolates and Dr. Jorge de Souza for his critical review.

\section{REFERENCES}

Agrios GN (1988). Plant Pathology. 3rd edn. Academic Press, New York.

Anderbrhan T and Furtek DB (1994). Random amplifield polymorphic DNA (RAPD) analysis of Crinipellis perniciosa isolates from different hosts. Plant Pathol. 43: 1020-1027.

Anderbrhan T, Figueira A, Yamada MM, Cascardo J, et al. (1999). Molecular fingerprint suggests two primary outbreaks of witches' broom disease (Crinipellis perniciosa) of Theobroma cacao in Bahia, Brazil. Eur. J. Plant Pathol. 105: 167-175.

Araújo WL, Maccheroni W Jr, Aguilar-Vildoso CI, Barroso PA, et al. (2001). Variability and interactions between endophytic bacteria and fungi isolated from leaf tissues of citrus rootstocks. Can. J. Microbiol. 47: 229-236.

Araújo WL, Lacava JL, Andreote FD and Azevedo JL (2008). Interactions between endophytes and plant host: Biotechnological aspects. Research Signpost, Trivandrum, Kerala, India.

Arnold AE, Mejia LC, Kyllo D, Rojas EI, et al. (2003). Fungal endophytes limit pathogen damage in a tropical tree. Proc. Natl. Acad. Sci. U. S. A. 100: 15649-15654.

Bastos CN, Anderbhran T and Almeida LC (1988). Comparação morfológica de isolados de Crinipellis perniciosa. Fitopatol. Bras. 13: 202-205.

Calle H, Cook AA and Fernando S (1982). Histology of witches' broom caused in cacao by Crinipellis perniciosa. Phytopathology 11: 1479-1481.

Carroll G (1988). Fungal endophytes in stems and leaves: from latent pathogen to mutualistic symbiont. Ecology 69: 2-9.

Freeman S and Rodriguez RJ (1993). Genetic conversion of a fungal plant pathogen to a nonpathogenic, endophytic mutualist. Science 260: 75-78.

Frias GA, Purdy LH and Schmidt RA (1995). An inoculation method for evaluating resistance of cacao to Crinipellis perniciosa. Plant Dis. 79: 787-791.

Griffith GW and Hedger JN (1994). The breeding biology of biotypes of the witches' broom pathogen of cacao, Crinipellis perniciosa. Heredity 72: 278-289.

Griffith GW, Bravo-Velasquez E, Wilson FJ, Lewis DM, et al. (1994). Ecology of Plant Pathogens. In: Autecology and Evolution of the Witches' Broom Pathogen (Crinipellis perniciosa) of Cacao (Blakeman JP and Williamson B, eds.). CAB International, Oxon, 245-267.

Manandhar HK, Lyngs Jorgensen HJ, Mathur SB and Smedegaard-Petersen V (1998). Suppression of rice blast by preinoculation with avirulent Pyricularia oryzae and the nonrice pathogen Bipolaris sorokiniana. Phytopathology 88: 735-739.

Muse R, Collin HA, Issac S and Hardwick K (1996). Effects of the fungus Crinipellis perniciosa, causal agent of witches' broom disease, on cell and tissue cultures of cocoa (Theobroma cacao L.). Plant Pathol. 45: 145-154.

Orchard J, Collin HA, Hardwick K and Isaac S (1994). Changes in morphology and measurement of cytokinin levels during the development of witches' broom on cacao. Plant Pathol. 43: 65-72.

Pontecorvo G, Roper JA and Forbes E (1953). Genetic recombination without sexual reproduction in Aspergillus niger. J. Gen. Microbiol. 8: 198-210.

Raeder U and Broda P (1985). Rapid preparation of DNA from filamentous fungi. Lett. Appl. Microbiol. 1: 17-20.

Redman RS, Dunigan DD and Rodriguez RJ (2001). Fungal symbiosis from mutualism to parasitism: who controls the outcome, host or invader? New Phytol. 151: 705-716.

Rubini MR, Silva-Ribeiro RT, Pomella AW, Maki CS, et al. (2005). Diversity of endophytic fungal community of cacao (Theobroma cacao L.) and biological control of Crinipellis perniciosa, causal agent of witches' broom disease. Int. J. Biol. Sci. 1: 24-33.

Sebastianes FLS, Maki CS, Andreote FD, Araújo WL, et al. (2007). Genetic variability and vegetative compatibility of Erythricium salmonicolor isolates. Sci. Agric. 64: 162-168.

Silva SDVM and Matsuoka K (1999). Histologia da interação Crinipellis perniciosa em cacaueiros susceptíveis e resistentes a vassoura-de-bruxa. Fitopatol. Bras. 24: 54-59. 
Sinclair JB and Cerkauskas RF (1996). Latent Infection vs. Endophytic Colonization by Fungi. In: Endophytic Fungi in Grasses and Woody Plants (Redlin SC and Carris LM, eds.). APS Press, Minessota, 3-30.

Wheeler BEJ and Mepsted R (1988). Pathogenic variability amongst isolates of Crinipellis perniciosa from cocoa (Theobroma cacao). Plant Pathol. 37: 475-488.

Yamada MM, Anderbrhan T and Furtek DB (1998). Genetic variability among isolates of Crinipellis perniciosa from solanaceous host and their relationship to isolates from Theobroma cacao. Agrotrópica 10: 123-126.

Yap I and Nelson RJ (1996). Winboot: a Program for Performing Bootstrap Analysis of Binary Data to Determine the Confidence Limits of UPGMA-Based Dendrograms. IRRI, Manilla (Discussion Paper Series, 14). 